\title{
RELATIONSHIP BETWEEN PERSONALITY AND STUDY HABITS IN UNIVERSITY ENGINEERING STUDENTS
}

\author{
Brav NMA ${ }^{1 *}$ and Trejo $\mathrm{FHA}^{2}$ \\ ${ }^{1}$ Universidad Nacional del Callao, Perú \\ ${ }^{2}$ Universidad Nacional Federico Villarreal, Perú
}

\begin{abstract}
The objective of this research is to establish the relationship between two variables: Personality and Study Habits. The research developed is descriptive correlational. The sample was represented by 92 students of the first cycles of Chemical Engineering of a public university of the constitutional province of Callao-Peru. The study was developed with students of the courses State, Society and Human Development, Methodology of University Work and Industrial Psychology. For this purpose, two time groups were formed (01Q and 02Q), and the Eysenck Personality Questionnaire (EPQR- A) was administered, this instrument evaluates the personality traits: Neuroticism, Extraversion and Psychoticism. On the other hand, Luis Vicuña's Study Habits Inventory evaluates the way students study, divided into five dimensions: How do you study, How do you do your homework, How do you prepare your exams, How do you listen to your classes and How do you accompany your study time? These are instruments that are used in the university system at an international level, they are used in the psycho-pedagogical area or for research. The results indicate a significant relationship between Personality and Study Habits. Therefore, it is demonstrated that there is a clear tendency towards the Psychoticism dimension, being very high; which is very unfavorable for a university student in this contemporary world. Likewise, it is verified that there is a considerable positive tendency towards the dimension of How do you study? There is a clear negative tendency towards the dimension of How do you do your homework? In addition, it is verified that there is a marked negative tendency towards How do you prepare your exams? which is very unfavorable for a university student.
\end{abstract}

Keywords: personality, neuroticism, extraversion, psychoticism, study habits

\section{Introduction}

Mondragon, Cardoso and Bobadilla S. (2016). Nowadays, the topic is very relevant since higher education institutions propose a new paradigm, through the development of knowledge and tools necessary to take advantage of diversity, the convergence of cultures, the large amount of information available and new discoveries provided by science and technology; therefore, if the student does not have a solid foundation of study habits, this lack has a negative impact on the activities carried out both in their academic, personal and professional training. It is also necessary to refer to the importance of personality traits in relation to the different study habits that can be assumed as part of their professional academic activity.

It is a clear reality that in certain careers and depending on the character of the university, there are high rates of students who fail or have low grades. It is even observed that there are students who are taking the same course for the second or third time. Of course, this situation is worrying for teachers and university authorities, who try to explain the reasons that lead to strong academic performance gaps in students of a semester regime, especially students in the first cycles of the career, especially when this belongs to the area of Engineering. 
For this reason, many answers are proposed as hypotheses; one of them being related to the personality of each student; and the other, to the way of studying. In fact, research developed in other universities in Peru and the world have shown that there is a clear relationship between personality and study habits. In fact, these variables have repercussions in the different academic activities of the student in formation; even in his daily life, at a personal, family and social level.

It is necessary to have clear that the independent variable, Personality and the dependent variable, Study Habits, will have a great relevance in the university academic environment, in a permanent way, since in this university space the student manages to develop greater academic abilities as a future professional, and mainly in the way they should study, it is there where it takes relevance and importance and from now on the present study is justified.

With respect to the objectives of the research developed, a fundamental objective has been set which synthesizes the investigated problem, which seeks to demonstrate if there is a relationship between personality and study habits in students of the Faculty of Chemical Engineering of the National University of Callao.

In this sense, the problem becomes acute when the university student does not find a satisfactory answer in his study notes. Above all, when he does not know that there are aspects of the Personality that favorably influence the different evaluations of the subjects to develop, such as being sociable, active, assertive, creative, etc. and on the other hand, when the young university student, apprentice in a certain way, has no idea of the importance of the study Habits, that is to say, he ignores that having adequate study habits, reading competence, concentration, study schedule, etc.; is transcendental in his professional formation.

Aldana (2013), points out that the importance of this type of research lies in the contribution to the sciences of higher education, showing quantifiable statistical data leading to appropriate interventions at appropriate times and thus contribute to the scientific training of future professionals; in turn, it guides professionals and university students to know the importance of studying these variables, which represent part of the university psychoeducational problem.

Rosales (2016), points out that age establishes significant differences in study habits and academic stress, likewise at the level of Study Habits it was found that 1 st and 3rd cycle students have better Study Habits.

The study habits that occur within the university system entail that the student must place himself in the different contents, to perform interpretation, analysis, assimilation and retention, so that later they can be expressed in debates, exams, conversations that the student maintains in his daily life. Da Silva and Reategui (2016), this leads to determine that study habits is an important factor for academic success, not only the act of studying, but also how this act is performed, since it involves bringing into play a series of skills and techniques that are obtained with daily practice.

Rojas (2018). Personality, is a variable to take into account in the academic field and in turn influences the forms of academic learning, in a study they point out that there is a significant relationship between brain dominance, personality dimensions and academic learning of university students. 
Muñoz (2019). Refers that personality traits can be considered as a scientific concept because it summarizes the behaviors that people perform in different situations and moments. Therefore, he concludes that traits are constructs that allow us to describe and study individual differences. From this it can be pointed out that the university student constructs his study habits according to his personality traits.

\section{Method}

The present research work is framed within a quantitative and theoretical approach, since it tries to respond to a theoretical problem and is oriented to describe reality. The design is descriptivecorrelational, and aims at evaluating the two independent and dependent variables, which are: Personality and Study Habits, respectively to then find the relationship between them.

The sample size is formed by the 92 students of the I and II cycle, of the Faculty of Chemical Engineering of the National University of Callao, which was obtained in a non-probabilistic way using a convenience sampling; since, the individuals are more accessible to the research. This technical procedure allows the proximity of the researcher to the individuals selected from a set of courses that are within the professional training areas of this career.

Likewise, for the statistical analysis of the data, use was made of Pearson's correlation coefficient test, which made it possible to evaluate the statistical relationship between two continuous variables. The data were processed through the SPSS 24 program, which allowed explaining the relationship between the dimensions of Personality and Study Habits in the students of the Faculty of Chemical Engineering of the National University of Callao.

The scope of the present study is oriented to the students of the first cycles of the Faculty of Chemical Engineering of the National University of Callao -Peru.

\section{Results and discussion}

The descriptive level is presented from the analysis of the results obtained from the administration of the instruments (Personality Questionnaire and Study Habits Inventory) to the sample of students of the National University of Callao.

For this purpose, use has been made of all the direct scores obtained in the students from the variables investigated, according to the rating and scoring system of the items, both in the Personality variable and in the Study Habits variable.

Table 1: Descriptive Statistics in the Total Sample for Personality and Study Habits.

\begin{tabular}{lccccc}
\hline Instrument & Mode & Instruments Median & Mean & Deviation & Variance \\
\hline $\begin{array}{l}\text { Personality } \\
\text { Questionnaire (P }\end{array}$ & 46.00 & 45,00 & 44,35 & 9,152 & 83,768 \\
$\begin{array}{l}\text { Inventory Of Study } \\
\text { Habits (Ish) }\end{array}$ & 19.00 & 23,00 & 23,68 & 6,065 & 36,790 \\
\hline
\end{tabular}




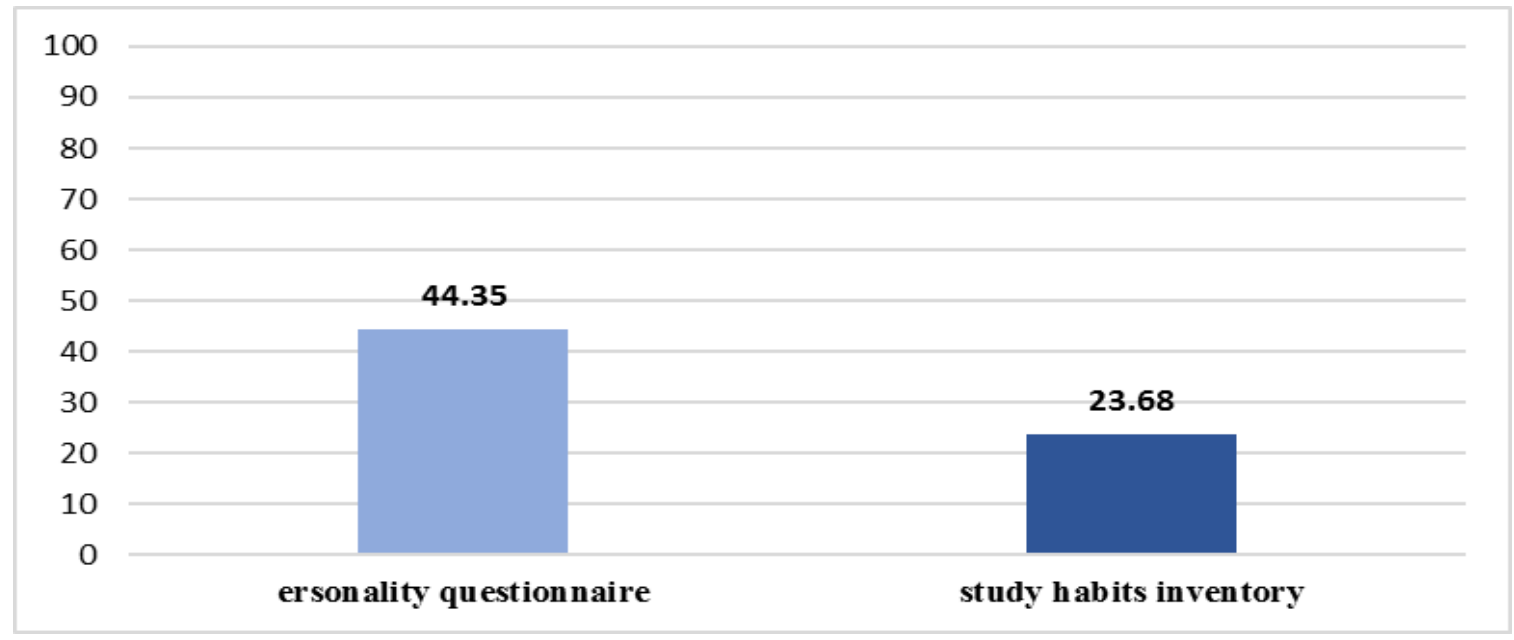

Figure 1: It can be seen that the variable Personality presents a specific average level (Mean), which expresses a predominance in $(X=44.35)$; while the variable Study Habits is lower in average (Mean), expressing itself in $(X=23.68)$. This indicates that Personality is predominant as an independent variable; and Study Habits is a dependent variable

Table 2: Dimensions and levels of Personality

\begin{tabular}{llll}
\hline Dimensions & Levels & Frequency & Percentage \\
\hline Extraversion & Very High & 34 & 37,0 \\
Neuroticism & Very High & 74 & 80,4 \\
Psycoticism & Very High & 92 & 100,0 \\
\hline
\end{tabular}

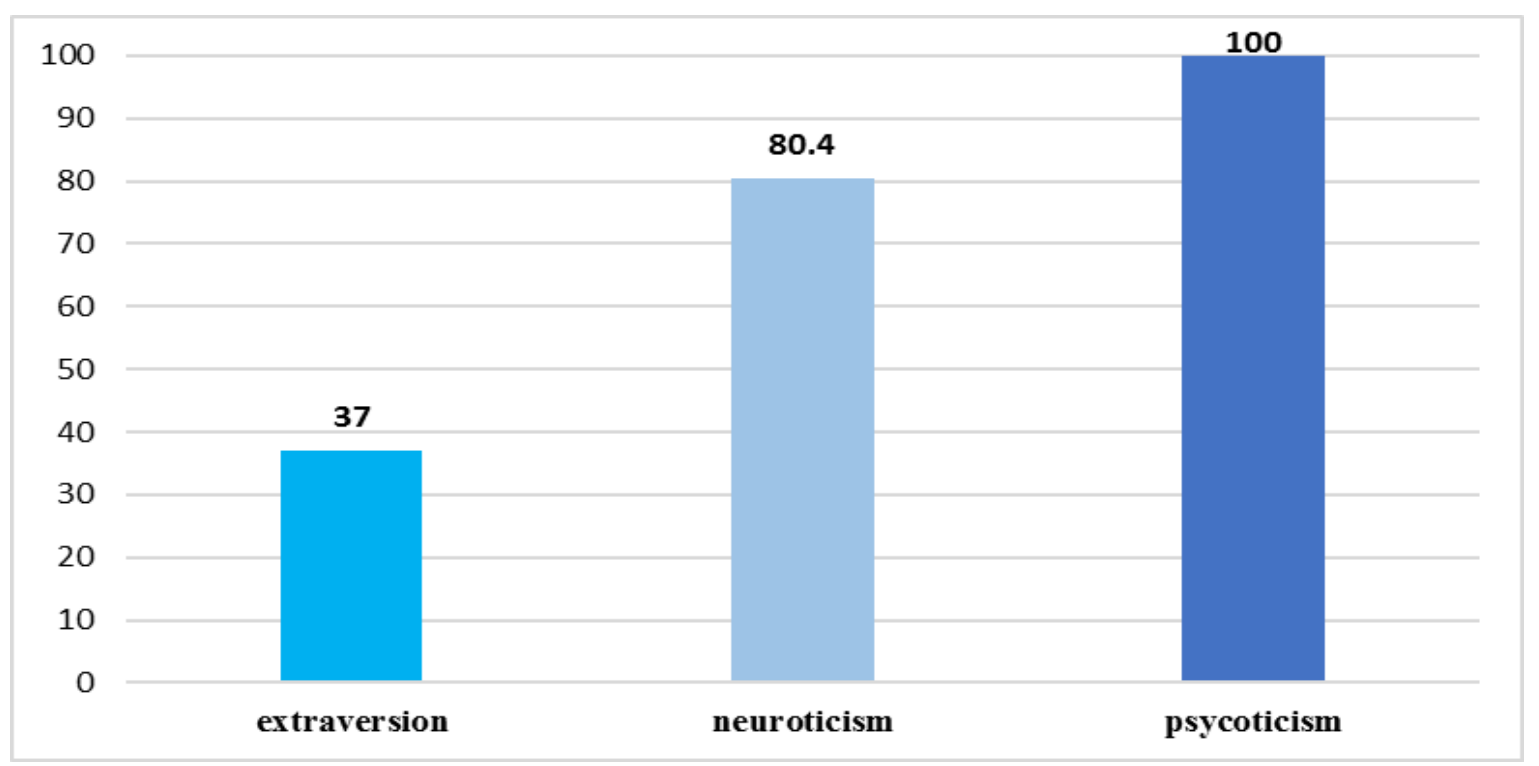

Figure 2: In Personality, it can be seen that $37.0 \%$ (34) present a clear tendency to very high with respect to the Extraversion dimension; $80.4 \%$ (74) present a clear tendency to very high with respect to the Neuroticism dimension; and 100.0\% (92) are very high with respect to the Psychoticism dimension; of the total number of students evaluated. 
Table 3: Relationship between the dimension of Personality and Study Habits in students.

\begin{tabular}{lll}
\hline & & Personality \\
\hline Study Habits & Correlation coefficient &, 535 \\
& Sig. (bilateral) &, 000 \\
& N & 92 \\
\hline
\end{tabular}

According to the results when applying Spearman's correlation coefficient, in the general hypothesis test, a Sig. $=0.000$ was found, a value that indicates that it is less than 0.01 ; and as such, the null hypothesis is rejected and the general hypothesis is accepted, which indicates that there is a significant relationship between the dimensions of Personality and Study Habits in Chemical Engineering students of the National University of Callao.

Table 4: Relationship between the Extraversion dimension and Study Habits in students.

\begin{tabular}{|c|c|c|c|c|}
\hline & & & IHE & $\mathrm{DE}$ \\
\hline \multirow{6}{*}{ Spearman'S Rho } & $\begin{array}{l}\text { Inventory Of Study Habits } \\
\text { (ISH) }\end{array}$ & $\begin{array}{l}\text { Correlation } \\
\text { coefficient }\end{array}$ & 1,000 &, $300 * *$ \\
\hline & \multirow{5}{*}{$\begin{array}{l}\text { Dimension Extraversion } \\
\text { (DE) }\end{array}$} & Sig. (bilateral) & . & ,004 \\
\hline & & $\mathrm{N}$ & 92 & 92 \\
\hline & & $\begin{array}{l}\text { Correlation } \\
\text { coefficient }\end{array}$ &, $300 * *$ & 1,000 \\
\hline & & Sig. (bilateral) & ,004 & . \\
\hline & & $\mathrm{N}$ & 92 & 92 \\
\hline
\end{tabular}

The results of the correlation of Spearman's coefficient, found values sig. $\mathrm{p}<0.01$, therefore, the null hypothesis is rejected and the research hypothesis is accepted, which indicates that there is a significant relationship between the Extraversion dimension and the Study Habits in the students of Chemical Engineering, of the National University of Callao.

Table 5: Relationship between the Neuroticism dimension and Study Habits in students.

\begin{tabular}{lll}
\hline & \multicolumn{1}{c}{ Neuroticism Dimension } \\
\hline Inventory Of Study Habits (IHE) & $\begin{array}{l}\text { Correlation } \\
\text { coefficient }\end{array}$ &, $421 * *$ \\
& Sig. (bilateral) &, 000 \\
& $\mathrm{~N}$ & 92 \\
\hline
\end{tabular}

The results of the correlation of Spearman's coefficient, found values sig. $\mathrm{p}<0.01$, therefore, the null hypothesis is rejected and the research hypothesis is accepted, which indicates that there is a significant relationship between the Neuroticism dimension and the Study Habits in the students of Chemical Engineering, of the National University of Callao. 
Table 6: Relationship between the Psychoticism dimension and Study Habits in students.

\begin{tabular}{|c|c|c|c|c|}
\hline & & & IHE & DP \\
\hline \multirow{6}{*}{$\begin{array}{l}\text { SPEARMAN'S } \\
\text { Rho }\end{array}$} & $\begin{array}{l}\text { Inventory Of Study } \\
\text { Habits (ISH) }\end{array}$ & $\begin{array}{l}\text { Correlation } \\
\text { Coefficient }\end{array}$ & 1,000 & ,266* \\
\hline & \multirow{5}{*}{$\begin{array}{l}\text { Psychoticism } \\
\text { Dimension (PD) }\end{array}$} & Sig. (bilateral) & . & ,010 \\
\hline & & $\mathrm{N}$ & 92 & 92 \\
\hline & & $\begin{array}{l}\text { Correlation } \\
\text { Coefficient }\end{array}$ & ,266* & 1,000 \\
\hline & & Sig. (bilateral) & & ,010 \\
\hline & & $\mathrm{N}$ & 92 & 92 \\
\hline
\end{tabular}

The results of the correlation of Spearman's coefficient, found values sig. $\mathrm{p}<0.01$, therefore, the null hypothesis is rejected and the research hypothesis is accepted, which indicates that there is a significant relationship between the Psychoticism dimension and the Study Habits in the students of Chemical Engineering of the National University of Callao.

Table 7: Dimensions and levels of Study Habits.

\begin{tabular}{lccc}
\hline Dimensions & Levels & Frequency & Percentage \\
\hline How do you study? & Very positive & 16 & 17,4 \\
How do you do your homework? & Positive & 3 & 3,3 \\
How do you prepare for your exams? & Positive & 1 & 1,1 \\
How do you listen to your classes? & Very positive & 2 & 2,2 \\
What accompanies your & Muy positivo & 3 & 3,3 \\
moments of study & & & \\
\end{tabular}

The study habits, it can be observed that $17.4 \%$ present a clear tendency to very positive regarding the dimension. How do you study? 3.3\% present a clear tendency to positive regarding the dimension How do you do your homework? $1.1 \%$ are positive regarding the dimension. How do you prepare for your exams? 2.2\% are very positive regarding the dimension. How do you listen to your classes? And $3.3 \%$ present a clear tendency to very positive regarding the dimension. How do you accompany your study moments of the total number of students evaluated?

Table 8: How do you study?

\begin{tabular}{lll}
\hline Levels & Frequency & Percentage \\
\hline Negative tendency & 6 & 6,5 \\
Positive trend & 35 & 38,0 \\
Positive & 35 & 38,0 \\
Very positive & 16 & 17,4 \\
TOTAL & 92 & 100,0 \\
\hline
\end{tabular}




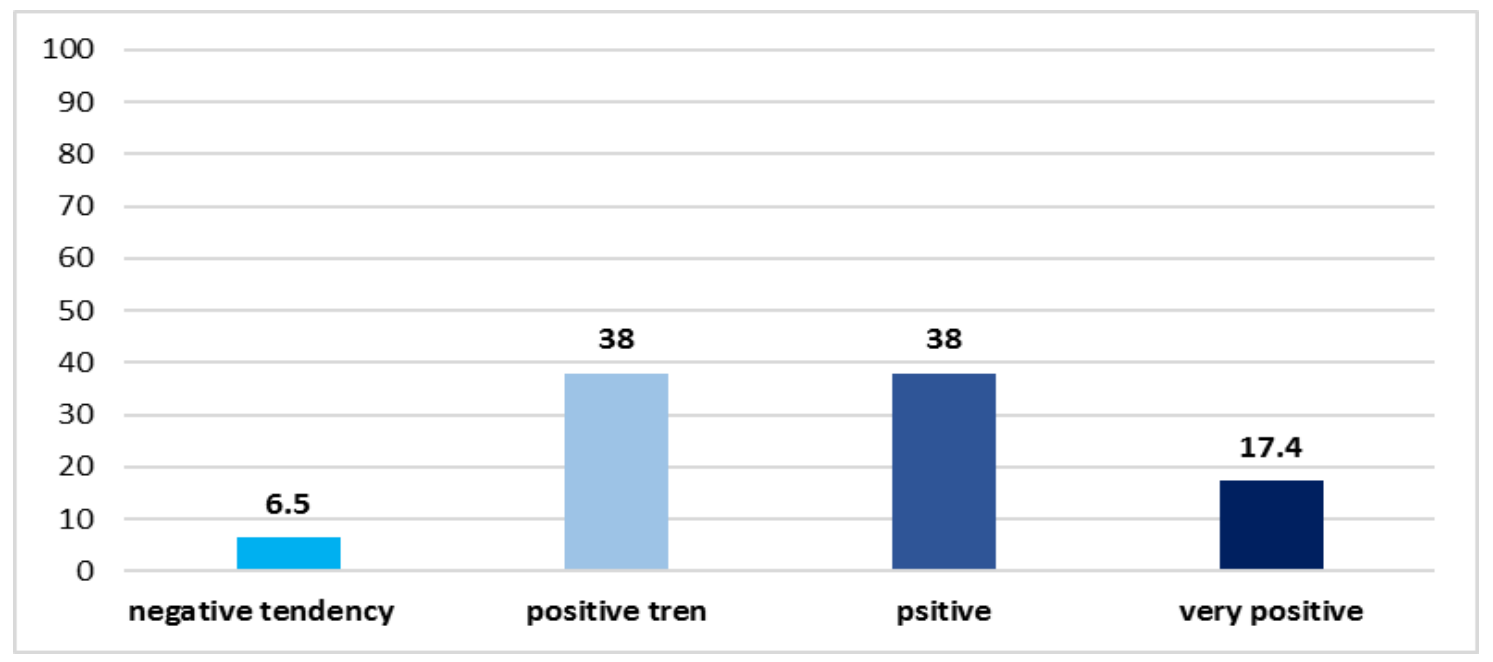

Figure 3: We can perceive with respect to the dimension how do you study? The majority of the respondents that is $38.0 \%$ (35) present a positive tendency; followed by $38.0 \%$ (35) present positive; $17.4 \%$ (16) are very positive and only $6.5 \%$ (6) present a negative tendency, out of a sample of 92 students evaluated.

Table 9: How do you do your homework?

\begin{tabular}{lll}
\hline Levels & Frequency & Percentage \\
\hline Negative & 27 & 29,3 \\
Negative tendency & 48 & 52,2 \\
Positive tendency & 14 & 15,2 \\
Positive & 3 & 3,3 \\
Total & 92 & 100,0 \\
\hline
\end{tabular}

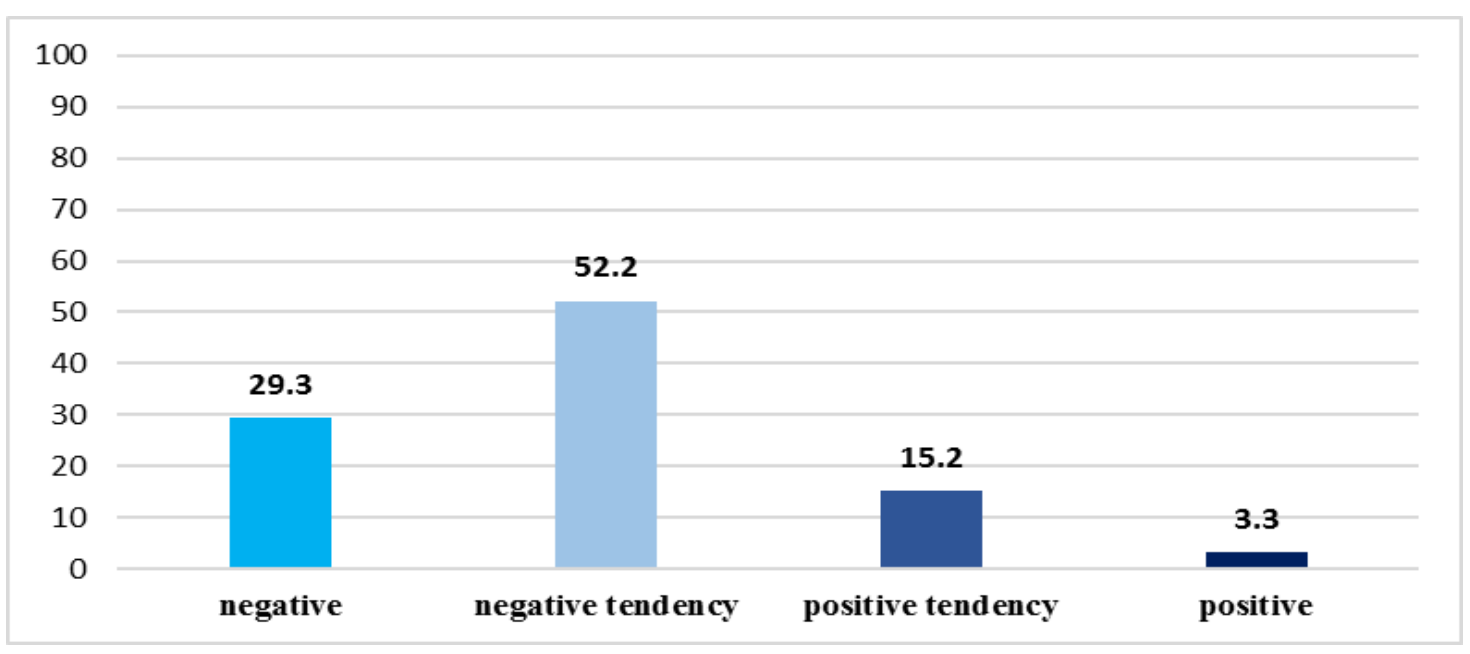

Figure 4: We can perceive with respect to the dimension How do you do your homework, the majority of the respondents $52.2 \%$ (48) present a negative tendency; followed by $29.3 \%$ (27) is negative, and $15.2 \%$ (14) presents a positive tendency; and only $3.3 \%$ (3) is positive, out of a sample of 92 students evaluated. 
Table 10: How do you prepare for your exams?.

\begin{tabular}{lll}
\hline Levels & Frequency & Percentage \\
\hline Very negative & 5 & 5,4 \\
Negative & 32 & 34,8 \\
Negative tendency & 39 & 42,4 \\
Positive tendency & 15 & 16,3 \\
Positive & 1 & 1,1 \\
Total & 92 & 100,0 \\
\hline
\end{tabular}

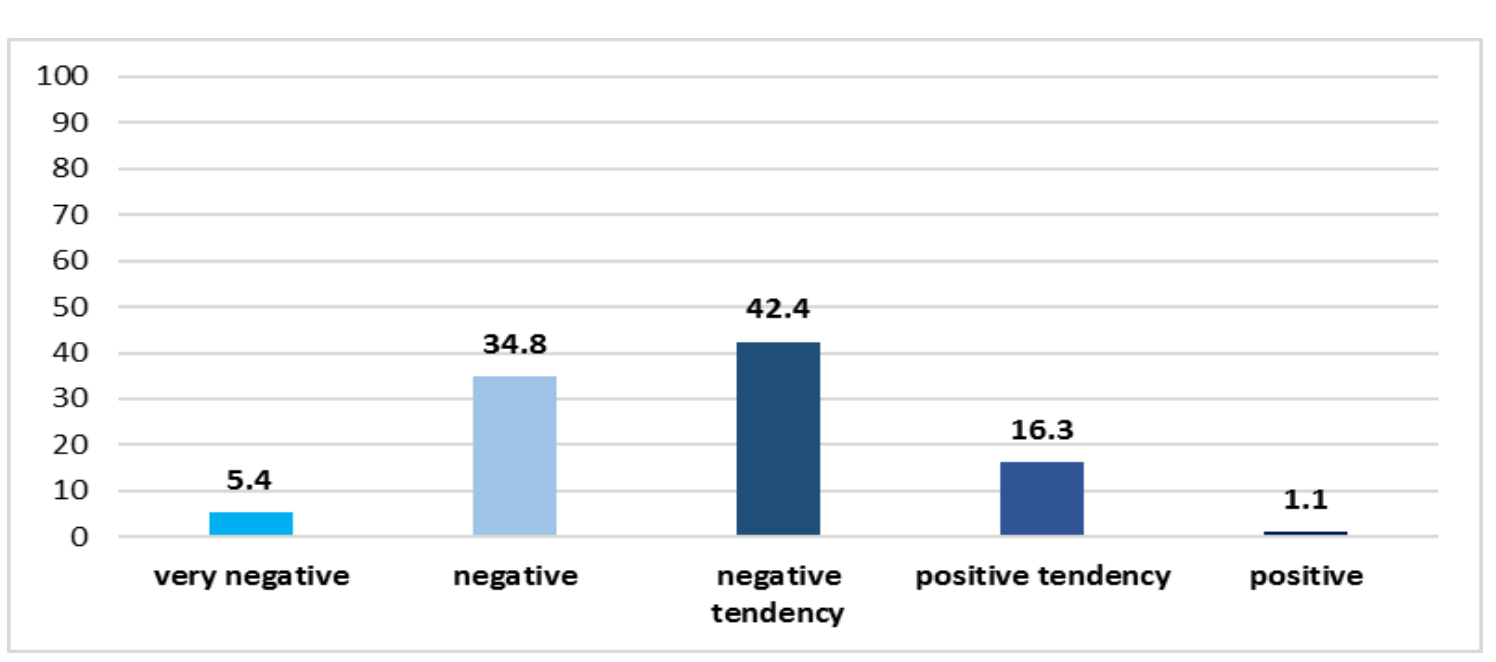

Figure 5: We can perceive with respect to the dimension How do you prepare your exams, the majority of the respondents $42.4 \%$ (39) present negative tendency, $34.8 \%$ (32) are negative; followed by $16.3 \%$ (15) present positive tendency; 5.4 (5) are very negative and only $1.1 \%$ (1) is positive, out of a sample of 92 students evaluated.

Table 11: How do you listen to your classes?.

\begin{tabular}{lll}
\hline Levels & Frequency & Percentage \\
\hline Very negative & 7 & 7,6 \\
Negative & 26 & 28,3 \\
Negative tendency & 32 & 34,8 \\
Positive tendency & 12 & 13,0 \\
Positive & 13 & 14,1 \\
Very positive & 2 & 2,2 \\
Total & 92 & 100,0 \\
\hline
\end{tabular}




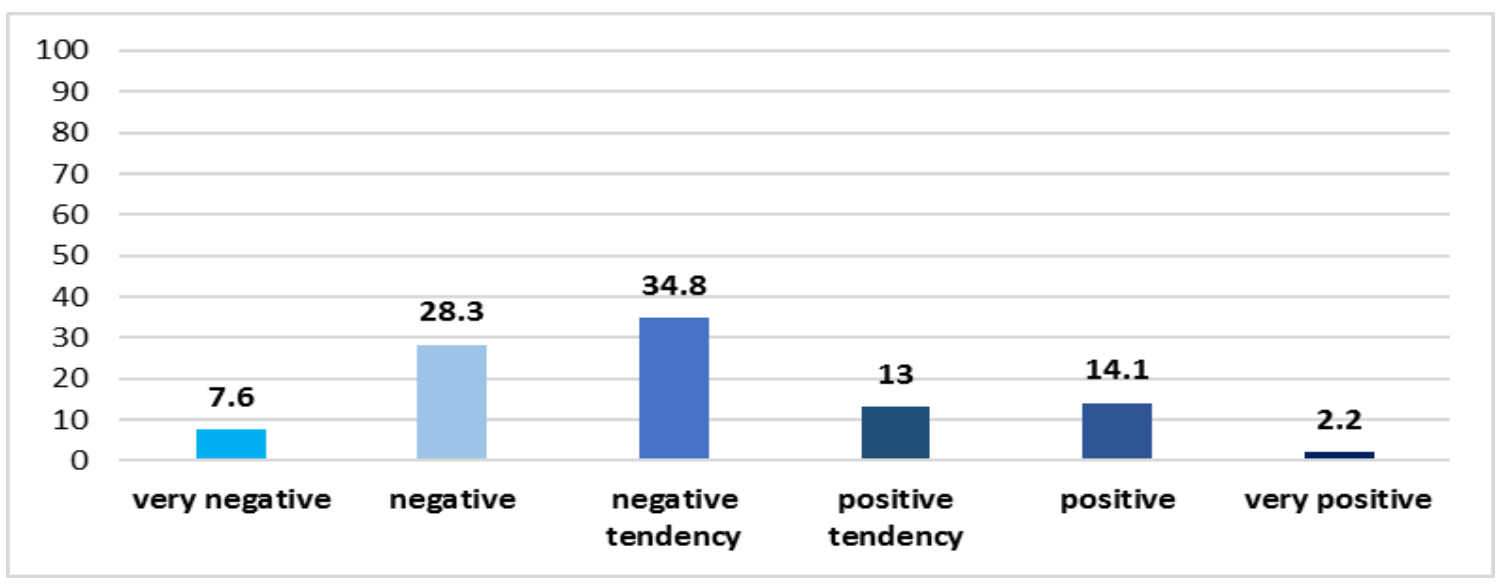

Figure 6: We can perceive with respect to the dimension How do you listen to your classes? The majority of the respondents, $34.8 \%$ (32) present negative tendency; $28.3 \%$ (26) are negative; followed by $14.1 \%$ (13) are positive; $13.0 \%$ (12) present positive tendency; 7.6 (7) are very negative, and only $2.2 \%$ (2) are very positive, out of a sample of 92 students evaluated.

Table 12: What accompanies your moments of study?.

\begin{tabular}{lll}
\hline Levels & Frequency & Percentage \\
\hline Very negative & 1 & 1,1 \\
Negative & 52 & 56,5 \\
Negative tendency & 24 & 26,1 \\
Positive tendency & 7 & 7,6 \\
Positive & 5 & 5,4 \\
Very positive & 3 & 3,3 \\
Total & 92 & 100,0 \\
\hline
\end{tabular}

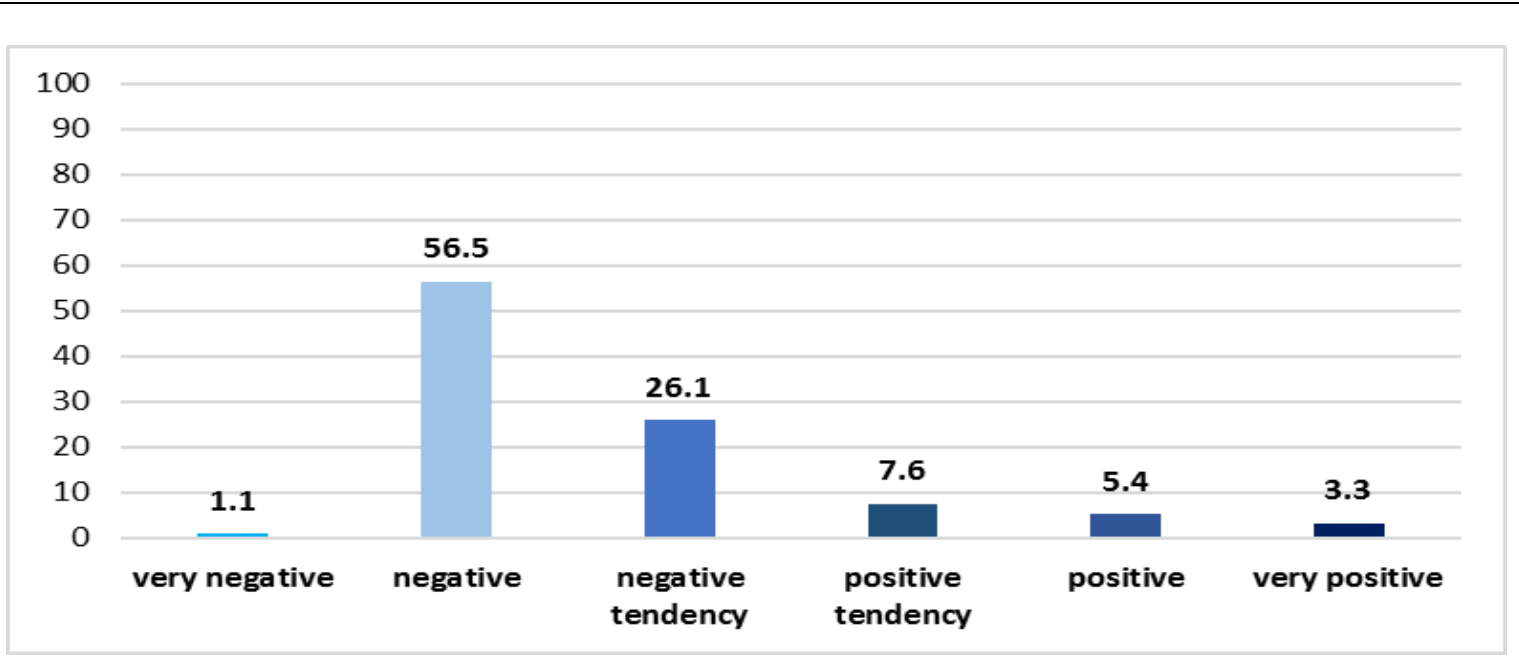

Figure 7: We can perceive with respect to the dimension "What accompanies your moments of study?", the majority of the respondents $56.5 \%$ (52) is negative; $26.1 \%$ (24) presents negative tendency; followed by $7.6 \%$ (7) presents positive tendency; 5.4 (5) is positive; $3.3 \%$ (3) is very positive, and only $1.1 \%$ (1) is very negative, from a sample of 92 students evaluated.

The results allow us to establish a discussion, in which the general hypothesis, it can be observed that there is a significant relationship between the dimensions of Personality and Study Habits in Chemical 
Engineering students of the National University of Callao, which is accepted. In this regard, we can mention that the students of the National University of Callao show a correlation between their personality characteristics and their study habits. In this regard the results presented in the research is referred to study habits; they also point out that there is a positive tendency against the preparation of their exams and academic work (Cuadro, Moran and Torres, 2017).

Intellectual work demands in the university student a permanent development of skills in which studying becomes a way of life and a habit of intellectual behavior. In their research, it is determined that study habits and academic performance of university students are significantly related. (Da Silva and Reategui, 2016).

Regarding one of the specific hypotheses, it is observed that there is a significant relationship between the Extraversion dimension and the Study Habits in Chemical Engineering students, of the National University of Callao, which is accepted. In this regard, we can point out that the students of the National University of Callao show a correlation between the Extraversion traits that are part of the personality and the study habits. Regarding the results presented in the research referred to personality, it has been proven that the Extraversion dimension predominates at an average level (Luján, 2018).

Regarding one of the specific hypotheses, it can be observed that there is a significant relationship between the Neuroticism dimension and the Study Habits in Chemical Engineering students, of the National University of Callao, which is accepted. In this regard, we can point out that the students of the National University of Callao, show correlation of Neuroticism traits that are part of the personality against study habits. Regarding the results presented in the research regarding personality, it has been proven that there are populations characterized by high levels or with higher trait of Neuroticism (Galindo, 2015 and Luján, 2018).

Regarding one of the specific hypotheses, there is a significant relationship between the Psychoticism dimension and the Study Habits in Chemical Engineering students of the National University of Callao, which is accepted. In this regard, we can point out that the students of the National University of Callao, demonstrate a significant relationship with respect to the Psychoticism dimension that is part of the personality in relation to study habits. In this regard the results presented in the research referred to personality, it was found that the traits of the Psychoticism dimension present low levels (Luján, 2018).

\section{Conclusion}

It was proved, at a general level, that there is a significant relationship between the dimensions of Personality and Study Habits in the students of Chemical Engineering, of the National University of Callao.

Personality is predominant as a variable since it is the independent variable as opposed to the variable Study Habits which is a dependent variable, which indicates that the designation of the variables has been adequate. 
It is shown that there is a negative tendency towards study habits, being 58.7\%; while it is positive towards study habits, only $3.3 \%$. Thus, it is evident that the students present a marked lack of adequate study habits.

It is verified that there is a very high tendency with respect to the Extraversion dimension (37.0\%), which is favorable for a university student.

It is verified that there is a very high tendency with respect to the Neuroticism dimension (80.4\%), which is very unfavorable for a university student.

There is a need to point out the limitations of the research conducted, first, it would have been appropriate that the number of the sample taken was larger, second, the sample would have been diverse, including all the students of the first two cycles of the different faculties of the university.

The suggestion that could be made for a future study is the implementation of a larger sample size.

\section{Acknowledgements}

To Mg. Psic. José Mariano Gabriel Eusebio, friend and colleague for his support and suggestions in the preparation of this article.

\section{References}

Anuel, A. and Bracho, A. (2014). Relationship between work-family interaction and personality characteristics of students of the Specialization in Public Management at the National Experimental Polytechnic University of the Armed Forces (UNEFA), Caracas. (Thesis at Central University of Venezuela). Caracas, Venezuela.

Allport, G. (1975). Personality, its configuration and development. Madrid, Spain: Editorial Cartoné.

Aldana, F. (2013). Relationship between Learning Styles and Stress Coping Styles in Students of the FIQ of the National University of Callao, 2013. Master's Thesis. Lima. Alas Peruanas University. Lima, Perú.

Alvarado, N. (2017). Relationship between personality dimensions and stress coping styles in students of the Faculty of Chemical Engineering of the National University of Callao. Research developed at the National University of Callao. FEDU.

APA (2020). APA Standards American Psychological Association. ( $7^{\text {th }}$ ed.). Javeriana Writing Center. Pontifical Javerian University, Sectional Cali.

Grados, J. and Alfaro, R. (2013). Study habits and academic performance in students of the 1st year of Psychology at the Peruvian Union University. Lima, Perù. Scientific Journal of Health Sciences, 6 (2), 23- 29.

Aragón, L. (2010). Personality profile of university psychology students: The case of the Faculty of Higher Education Iztacala. Educational Profiles, 33(133), 68- 87.

Arco, J. and Fernández, F. (2011). Effectiveness of a peer tutoring program in improving the study habits of university students. Journal of Psychodidactics, 16 (1), 163-180. https://www.redalyc.org/articulo.oa?id=175/17517217009

Candia, Z. (2015). Study habits in students of the fifth year of high school of the educational institution No. 093, Manuela Felicia Gomez, La Victoria, 2015. (Thesis for the professional degree in education). Cesar Vallejo University, Lima, Perú. 
Capdevila, A., Bellmunt, H. and Hernando, C. (2015). Lifestyle and academic performance in adolescents: comparison between athletes and non-athletes. Challenges, 27 (1), $28-33$.

Cassaretto, M. (2009). Relationship between the five major dimensions of personality and coping in pre-university students in Metropolitan Lima. (Thesis for the academic degree of Master in Psychology with mention in Clinical and Health Psychology). National Major University of San Marcos.

Cattell, R. (1940). Personality and other coefficients of similar patterns. ( $2^{\text {nd }}$ ed.). Barcelona, Spain. Editorial Fontanella.

Cattell, R. (1995). Personality Questionnaire Manual 16 PF. $2^{\text {nd }}$ edition. Madrid, Spain: TEA editions. S.A.

Cervone, D. and Pervin, L. (2009) Personality, theory and research. (2 $2^{\text {nd }}$ ed.). Mexico City, Mexico: Editorial Manual Moderno.

Clonninger, S. (2002). Theories of Personality. (2 $2^{\text {nd }}$ ed.). Mexico City, Mexico: Pearson Education.

Coolican, H. (2005). Research Methods and Statistics in Psychology. ( $3^{\text {rd }}$ ed.). Mexico City, Mexico: Editorial Manual Moderno.

Contreras, V. Cuba, V., Flores, G. Salinas, P. and Sulca, M. (2017). Study Methods. (Manual). San Martín de Porres University. Lima, Perú.

Cloninger, S. (2003) Theories of personality. (3rd ed.). Mexico City, Mexico: Editorial Pearson Education.

Covey, S. (2003). The seven habits of highly effective people. ( $1^{\text {st }}$ ed.). Buenos Aires, Argentina: Paidós.

Cuadros, V., Moran, B. and Torres, A. (2017). Study habits, willingness to study and academic performance in technical vocational training students of an armed institute. (Thesis for the Master's degree in teaching and university management), Marcellin Champagnat University.

Dolores, M. (2015). Emotional Intelligence and Personality of Drama Students: What defines them as actors and directors? (Doctoral Thesis). University of Murcia. Murcia, Spain.

Duane, P. (2010). Theories of the Editorial Personality. ( $9^{\text {th }}$ ed.). Cergange learning.

Escalante, L., Escalante, Y., Linzaga, C. and Merlos, M. (2011). Students' behavior as a function of their study habits. Current Research in Education, 8(2), 1- 15. https://academic.microsoft.com/paper/2061423956

Eysenck, H. (1985). Personality Dimensions of Students and Some Educational Implications of Eysenck's Theory of Extraversion and Neuroticism.

Galindo, D. (2015). Emotional Intelligence and Personality of Dramatic Art Students: ¿What Defines Them as Actors and Directors? Doctoral Thesis, University of Murcia, Murcia- Spain.

Hernández, R., Fernández, C. and Baptista, P. (2014). Research Methodology. (6 ${ }^{\text {th }}$ ed.). México, D.F., México: McGraw-Hill Interamericana.

Hjelle, L. and Ziegler, D. (1992). Personality Theories; basic assumptions, research, and applications. New York. Editorial McGraw-Hill. EEUU.

López-Ibor, J., Ortiz, J. and López-Ibor, M. (1999). Personality from trait theory. Lessons in medical psychology. Spain: Masson. p. 137. http://books.google.com.pe/books?id=d_rAkAg6MEC\&printsec=frontcover\&dq=isbn:8432134686\&hl=es\&cd=1\&redir_e $\mathrm{sc}=\mathrm{y} \# \mathrm{v}=$ onepage $\& \mathrm{q} \& \mathrm{f}=$ false

Luján, A. (2018). Personality traits in menopausal patients attending the Hospital Nacional Arzobispo Loayza. (Thesis for the professional degree of Psychology). UIGV, Perú.

Márquez, E. (1995). Study habits and personality. Mexico: Editorial Trillas.

Márquez, S. and Mondragón, R. (1987). Study habits and self-control. D.F., México. Editorial Trillas. 
Maslow, A. (1991). Motivation and Personality. Madrid, Spain: Editorial Díaz of Santos.

Quelopana, J. (2008). Methodological and scientific guide for students. Lima, Peru. Editorial San Marcos.

Ramos, J., Broco, L., Sánchez, A. and Doll, A. (2020). Personality as unidimensional and bidimensional vulnerability: The mediating role of cognitive variables on symptomatological severity in a sample of persons with severe personality disorder. Clinical and Health, 31(1) 1- 12. http://scielo.isciii.es/scielo.php?script=sci_arttext\&pid=S1130-52742020000100001

Rosales, J. (2016). Academic Stress and Study Habits in undergraduate students of Psychology at a Private Higher Education Center in Lima- South. (Bachelor's Thesis). Autonomous University. Lima, Perú.

Santiago, A. (2003). Study Habits. D.F., México. Editorial Interamericana.

Vicuña, L. (1999). Study Habits Inventory. Lima, Perú: Editions CEDEIS.

Vigo, J. (2007). Influence of study habits on the academic performance of students in the Instituto Superior Tecnológico Huando. (Bachelor's thesis). César Vallejo University. Lima, Perú.

Mondragon, Cardoso and Bobadilla S. (2016). Study habits and academic performance. Case undergraduate students in Administration of the professional academic unit Tejupilco, 2016. Tejupilco- Mexico. Iberoamerican Journal of Educational Research and Development, 8 (15), 1- 25. igaci\%c3\%93n\%20fiq\%20unac/investigaciones/habitos\%20de $\% 20$ estudio/internacionales $\% 20$ (poner \%20en\%20el\%20informe\%20tercero) /2. \%20mondragon\%20(2016).pdf.

Da Silva, and Reátegui (2016). Relationship between study habits and academic performance in students of the National University of the Peruvian Amazon - Iquitos 2016. Bachelor's thesis. National University of the Peruvian Amazon, Iquitos-Lima.

Rojas H. (2018). Brain dominance, basic dimensions of personality and academic learning in students of the Professional School of Education of the UNJBG of Tacna. Thesis to opt for the degree of Doctor of Educational Sciences. Enrique Guzmán y Valle University. 